\title{
Fruit Characteristics of Some Erect Blackberry Cultivars
}

\author{
P. Perkins-Veazie' and J.K. Collins ${ }^{2}$ \\ South Central Agricultural Research Laboratory, Agricultural Research \\ Service, U.S. Department of Agriculture, Lane, OK 74555
}

J.R. Clark ${ }^{3}$

Fruit Substation, University of Arkansas, Clarksville, AR 72830

Additional index words. Rubus spp., quality, seeds, color, small fruit

During the past 20 years, tetraploid thorny and thornless blackberry (Rubus spp.) cultivars have been developed in the Arkansas breeding program that exhibit an erect growth habit (Clark and Moore, 1990; Moore and Clark, 1988). The objective of this study was to compare the fruit and pyrenes (seed and endocarp) of one thornless and three thorny erect cultivars.

'Navaho' (thornless), 'Cheyenne', 'Shawnee', and 'Choctaw' (all thorny) blackberries were harvested at the dull-black stage of ripeness on three dates in 1992 from plants at the Clarksville, Ark., field station. Fruit were shipped on ice to Lane, Okla. Ten fruit per cultivar per harvest were weighed, number of drupelets per fruit was counted by using a white acrylic pen, and fruit were homogenized in a blender (Association of Official Analytical Chemists, 1984) to separate pyrenes from flesh. Length, width, and thickness of pyrenes were measured to $0.01 \mathrm{~mm}$ using a dissecting microscope (Fig. 1). Pyrene dry weights were measured in three replications of 100 pyrenes each. Thirty weighed, dried pyrenes per cultivar were used to determine volume by measuring specific gravity with distilled water and ethanol (6\% to $10 \%)$ solutions.

Surface color was measured on two sides on each of 10 fruit using a tristimulus calorimeter (model CR200, Minolta, Ramsey, N.J.). Firmess was measured on three drupelets per fruit using a penetrometer (Correx; Wagner Instruments, Westbury, Corm.) adapted for drupelet epidermal penetration by attaching a 0.3-mm-diameter wire (Abeles, 1986). Ten fruit halves $(\approx 5 \mathrm{~g})$ were homogenized, double-extracted with acidified ethanol $(0.22$ $\mathrm{M} \mathrm{HC}$ ), and strained through four layers of cheesecloth, and the extract absorbance was measured at $532 \mathrm{~nm}$ with a spectrophotometer (Shimadzu Corp., Kyoto, Japan) to determine anthocyanin concentration (absorbance units

Received for publication 4 Jan. 1993. Accepted for publication 25 Mar. 1993. We thank Shelia Magby, Sherry Winship, and Less Lackey for their technical assistance. The cost of publishing this paper was defrayed in part by the payment of page charges. Under postal regulations, this paper therefore must be hereby marked advertisement solely to indicate this fact.

'Plant Physiologist.

${ }^{2}$ Food Technologist.

${ }^{3}$ Resident Director and Associate Professor. per gram) (Sapers et al., 1986). Cultivar data replicated over time were analyzed by analysis of variance and means were separated by least significant difference.

'Shawnee' fruit had the highest fresh weight (Table 1), as reported by Moore and Clark

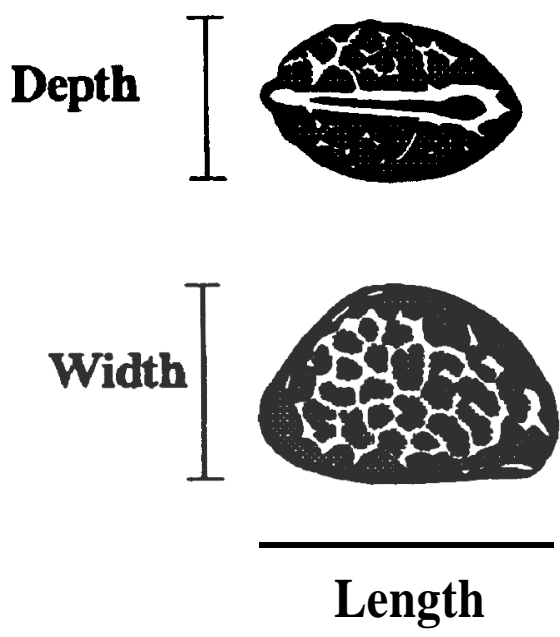

Fig. 1. Orientation of blackberry pyrene for length, width, and thickness measurements.
(1988). 'Navaho' fruit had fewer drupelets but a higher fresh weight per drupelet than fruit from thorny cultivars. 'Navaho' fruit were lighter in color (higher ' $L$ ' value) and lower in anthocyanin content than the other cultivars. Skin resistance to penetration was highest for 'Navaho' and 'Shawnee' and lowest for 'Choctaw' drupelets. 'Navaho' has been ranked most firm and 'Choctaw' least firm in subjective measurements (Clark and Moore, 1990); this perceived firmness may be related partially to skin toughness.

Small pyrene size, based on weight, is desirable in processed products (Jennings, 1988). 'Navaho' pyrenes were heavier, wider, and thicker than those of the other cultivars, although all pyrenes had similar densities (Table 2). Differences in pyrene dimensions in other germplasm and growing regions need to be evaluated.

Fruit of the erect thornless 'Navaho' had fewer drupelets, less anthocyanin, and larger pyrenes than fruit of the thorny cultivars. The high skin firmness values for 'Navaho' indicate that it has good potential for the fresh market.

\section{Literature Cited}

Abeles, F.B. 1986. Role of ethylene in Lactuca sativa $\mathrm{CV}$. 'Grand Rapids' seed germination. Plant Physiol. 81:780-787.

Association of Official Analytical Chemists. 1984 Official methods of analysis. Assn. Offic. Anal Chemists, Arlington, Va. p. 417.

Clark J.R. and J.N. Moore. 1990. Short-term fruit storage performance of Arkansas blackberry cultivars. Ark. Farm Res. 39:9.

Jennings, D.L. 1988. Raspberries and blackberries: Their breeding, diseases and growth. Academic New York. p. 179-182.

Moore, J.N. and J.R. Clark. 1988. 'Navaho': An erect thornless blackberry. Ark. Farm Res. 37:17.

Sapers, G. M., K.B. Hicks, A.M. Burgher, D.L. Hargreave, S.M. Sondey, and A. Bilyk. 1986. Anthocyanin patterns in ripening thornless blackberries. J. Amer. Soc. Hort. Sci. 111:945-950.

Table 1. Characteristics of blackberries at the dull black stage from thornless (Navaho) and thorny (Cheyenne, Choctaw, Shawnee) erect Arkansas cultivars.

\begin{tabular}{|c|c|c|c|c|c|c|}
\hline \multirow[b]{2}{*}{ Cultivar } & \multirow{2}{*}{$\begin{array}{c}\text { Berry } \\
\text { wt } \\
\text { (g) }\end{array}$} & \multirow{2}{*}{$\begin{array}{l}\text { Drupelets/ } \\
\text { fruit } \\
\text { (no.) }\end{array}$} & \multirow{2}{*}{$\begin{array}{l}\text { Fresh wt } \\
\text { drupelet } \\
\text { (mg) }\end{array}$} & \multirow{2}{*}{$\begin{array}{l}\text { Penetrometer } \\
\text { resistance } \\
(\text { skin }) \\
\left(\mathrm{N} / \mathrm{m}^{2} \times 10^{4}\right)\end{array}$} & \multicolumn{2}{|c|}{ Fruit color } \\
\hline & & & & & L value ${ }^{z}$ & $\begin{array}{c}\text { Anthocyanin } \\
\left(\mathrm{AU}^{\mathrm{y}} / \mathrm{g}\right)\end{array}$ \\
\hline Cheyenne & 5.9 & 79 & 74.7 & 17.0 & 20.4 & 122.4 \\
\hline Choctaw & 5.5 & 71 & 69.0 & 14.6 & 21.4 & 103.0 \\
\hline Shawnee & 6.8 & 78 & 87.2 & 19.7 & 22.0 & 111.2 \\
\hline Navaho & 5.3 & 48 & 110.4 & 20.7 & 25.3 & 90.1 \\
\hline $\operatorname{LSD}_{(\leq 0.05)}$ & 0.8 & 10 & 8.9 & 1.1 & 1.5 & 5.2 \\
\hline
\end{tabular}

${ }^{2}$ Value (lightness or darkness) obtained from measurements made in CIELAB System with Minolta tristimulus colorimeter.

${ }^{y}$ Absorbance units.

Table 2. Characteristics of pyrenes from Arkansas blackberries.

\begin{tabular}{lccccr}
\hline Cultivar & $\begin{array}{c}\text { Dry } \\
\text { wt } \\
(\mathrm{mg})\end{array}$ & $\begin{array}{c}\text { Length } \\
(\mathrm{mm})\end{array}$ & $\begin{array}{c}\text { Width } \\
(\mathrm{mm})\end{array}$ & $\begin{array}{c}\text { Thickness } \\
(\mathrm{mm})\end{array}$ & $\begin{array}{r}\text { Vol } \\
(\mu \mathrm{l})\end{array}$ \\
\hline Cheyenne & 2.22 & 3.31 & 1.94 & 1.10 & 2.31 \\
Choctaw & 1.87 & 3.15 & 1.84 & 1.08 & 2.01 \\
Shawnee & 3.06 & 3.57 & 2.03 & 1.32 & 3.22 \\
Navaho & 3.50 & 3.20 & 2.56 &. & 1.71 \\
LSD $_{(\leq 0.05)}$ & 0.19 & 0.17 & 0.13 & 0.09 & 0.15 \\
\hline
\end{tabular}

